\title{
PENGATURAN KLAUSULA BAKU DALAM UNDANG-UNDANG PERLINDUNGAN KONSUMEN DAN HUKUM PERJANJIAN SYARIAH
}

\author{
M. Roji Iskandar \\ Universitas Islam Bandung \\ Jl. Ranggagading No.8 Bandung, Indonesia \\ mrojiiskandar@unisba.ac.id
}

\begin{abstract}
Abstrak
Klausula baku adalah setiap aturan atau ketentuan dan syarat-syarat yang telah dipersiapkan dan ditetapkan terlebih dahulu secara sepihak oleh pelaku usaha yang dituangkan dalam suatu dokumen dan/atau perjanjian yang mengikat dan wajib dipenuhi oleh konsumen. Pembuat undang-undang ini menerima kenyataan bahwa pemberlakukan standar kontrak adalah suatu kebutuhan yang tidak bisa dihindari. Penelitian ini menggunakan pendekatan yuridis normatif dengan pendekatan comparative. Teknis analisis data yang digunakan dalam penelitian ini adalah metode kualitatif normatif. Hasil penelitian menunjukan bahwa pada dasarnya, dalam hukum perjanjian syariah ketentuan mengenai klausula baku bersumber dari asas al-hurriyah (kebebasan berkontrak) yang dituangkan dalam prinsip "Antarâdhin minkum” sebagaimana diatur dalam Q.S al-Nisa (4) ayat 29. Landasan keabsahan klausula baku dalam hukum perjanjian syariah terdapat dalam prinsipprinsip perjanjian, seperti prinsip al-hurriyah, prinsip al-'Adl, prinsip amah, prinsip al-shidiq dan prinsip itikad baik.
\end{abstract}

\section{Kata Kunci: Klausula Baku, Perlindungan Konsumen, Perjanjian Syariah}

\begin{abstract}
The standard clause is any rule or provision and conditions that have been unilaterally prepared and determined in advance by the business actor as outlined in a document and / or agreement that is binding and must be fulfilled by the consumer. These lawmakers accept the fact that the adoption of contract standards is a necessity that cannot be avoided. This study uses a normative juridical approach with a comparative approach. The technical analysis of the data used in this study is a normative qualitative method. The results showed that basically, in the Shariah treaty law the provisions regarding the standard clause were derived from the principle of al-Hurriyah (contracted freedom) as outlined in the principle "Antarâdhin minkum" as stipulated in QS al-Nisa (4) verse 29. The basis of the validity of the standard clause in sharia treaty law contained in the principles of the agreement, such as the principle of al-hurriyah, the principle of al-'Adl, the principle of amah, the principle of al-shidiq and the principle of good faith.
\end{abstract}

\section{Key word: Standard Clause, Consumer Protection, Sharia Agreement}

\section{PENDAHULUAN}

\section{A. Latar Belakang Masalah}

Sehubungan dengan standar

kontrak adalah penggunaan klausula baku dalam transaksi konsumen. Yang dimaksud dengan klausula baku menurut Pasal 1 angka 10 Undang-Undang Perlindungan Konsumen klausula baku 
adalah setiap aturan atau ketentuan dan syarat-syarat yang telah dipersiapkan dan ditetapkan terlebih dahulu secara sepihak oleh pelaku usaha yang dituangkan dalam suatu dokumen dan/atau perjanjian yang mengikat dan wajib dipenuhi oleh konsumen.

Pembuat undang-undang ini menerima kenyataan bahwa pemberlakukan standar kontrak adalah suatu kebutuhan yang tidak bisa dihindari sebab sebagaimana dikatakan oleh Syahdeini, perjanjian baku/ standar kontrak adalah suatu kenyataan yang memang lahir dari kebutuhan masyarakat (Syahdeni, 1993). Namun demikian, dirasa perlu untuk mengaturnya sehingga tidak disalahgunakan dan atau menimbulkan kerugian bagi pihak lain. Tinggal bagaimana pengawasan penggunaan standar kontrak itu sehingga tidak dijadikan sebagai alat untuk merugikan orang lain (Sidabalok, 2010).

$$
\text { Pasal } 18 \quad \text { Undang-Undang }
$$

Perlindungan Konsumen membuat sejumlah larangan penggunaan klausula baku dalam (standar) kontrak.Dari ketentuan Pasal 18 Undang-Undang Perlindungan Konsumen, larangan penggunaan standar kontrak dikaitkan dengan dua hal, yaitu isi dan bentuk penulisannya. Dari segi isinya, dilarang menggunakan standar kontrak yang memuat klausula-klausula yang tidak adil. Sedangkan dari segi bentuk penulisannya, klausula-klausula itu harus dituliskan dengan sederhana, jelas, dan terang sehingga dapat dibaca dan dimengerti dengan baik oleh konsumen.

Di samping itu, undang-undang ini mewajibkan pelaku usaha untuk segera menyesuaikan standar kontrak yang dipergunakannya dengan ketentuan undang-undang ini. Jika dalam kenyataannya masih tetap dipakai standar kontrak yang tidak sesuai dengan ketentuan di atas, akibat hukumnya adalah batal demi hukum. Artinya, bahwa klausula itu dianggap tidak ada, karena itu tidak mempunyai kekuatan hukum. Larangan dan persyaratan tentang penggunaan standar kontrak di atas dimaksudkan untuk menempatkan kedudukan konsumen setara dengan pelaku usaha berdasarkan prinsip kebebasan berkontrak dan mencegah kemungkinan timbulnya tindakan yang merugikan konsumen karena faktor ketidaktahuan, kedudukan yang tidak seimbang, dan sebagainya yang mungkin dapat dimanfaatkan oleh pelaku usaha untuk memperoleh keuntungan.

Ketentuan klausula baku ini dalam aplikasinya diterapkan dalam beberapa sektor bisnis oleh lembaga atau instansi seperti perbankan dan lain sebagainya. 
Dengan berkembangnya perbankan syariah

di Indonesia yang menggunakan kontrak/akad yang memiliki standar atau adanya klausula baku, maka dalam hal ini hukum perjanjian syariah berperan dalam memberikan dhawabit (kriteria/batasan) agar dalam tataran impelementasinya klausula baku yang terjadi tidak menyalahi prinsip-prinsip perjanjian syariah. Berdasarkan latarbelakang diatas maka rumusan masalah yang akan di bahas, pertama, bagimanakah konsep klausula baku dalam hukum perlindungan konsumen?, kedua, bagaimana ketentuan pengaturan klausula baku dalam perspektif hukum perikatan syariah?. Tujuannya untuk mengetahui konsep klausula baku dalam hukum perlindungan konsumen dan ketentuan pengaturan klausula baku dalam perspektif hukum perikatan syariah. Serta memberikan manfaat secara teoritis dan praktisi.

Penelitian ini menggunakan pendekatan yuridis normatif, yaitu dengan mengkaji atau menganalisis data sekunder yang berupa bahan-bahan hukum sekunder dengan memahami hukum sebagai perangkat peraturan atau norma positif di dalam perundang - undangan yang berlaku, jadi penelitian ini dipahami sebagai penelitian kepustakaan, yaitu penelitian terhadap bahan sekunder,
(Soerjono Soekanto \& Sri Mamudji, 1985, 15).

Disamping itu penelitian ini menggunakan pendekatan comparative atau perbandingan, Sifat penelitian ini adalah penelitian deskriptif analitis yaitu untuk menggaambarkan masalah (Rianto Adi, 2004, 130). Diperlukan juga bahan hukum tersier, seperti kamus dan ensiklopedia baik hukum maupun umum yang berbahasa Arab, Inggris dan Indonesia (Saputra, 2017). Teknis analisis data yang digunakan dalam penelitian ini adalah metode kualitatif normatif. Analisis terhadap data sekunder yang bersifat kualitatif tersebut dilakukan dengan cara berlandaskan pada teori hukum ataupun doktrin hukum yang terdapat pada kerangka pikir, kemudian diterapkan secara deduktif terhadap identifikasi masalah dari penelitian tesis ini, yang selanjutnya akan ditarik suatu kesimpulan yang bisa menjawab permasalahanpermasalahan yang menjadi masalah dalam penulisan ini.

\section{PEMBAHASAN}

A. Konsep Klausula Baku dalam Hukum Perlindungan Konsumen

1. Pengertian Klausula Baku

Teori deu care tentang kewajiban perusahaan terhadap konsumen didasarkan 
pada gagasan, baha pembeli dan konsumen tidak saling sejajar, dan bahwa kepentingan konsumen sangat rentan terhadap tujuan perusahaan yang memiliki pengetahuan dan keahlian yang tidak dimiliki konsumen. Karena produsesn berada pada posisi yang lebih menguntungkan, maka mereka berkewajiban untuk menjamin kepentingan konsumen agar tidak dirugikan (Pieries \& Widiarty, 2007). Karena konsumen harus bergantung pada kehalian produsesn dan pelaku usaha, maka produsesn tidak hanya berkewajiban memberikan produk yang sesuai dengan klaim yang dibuatnya. Namun juga harus berhati-hati untuk mencegah kerugian konsumen, meskipun produsen secara eksplisit menolak pertanggungjawaban seperti ini dan konsumen menerima penolakan tersebut dalam bentuk perjanjian klausula baku (Zulham, 2013).

Klausula baku biasanya dibuat oleh pihak yang kedudukannya lebih kuat, yang dalam kenyataannya bisa dipegang oleh pelaku usaha. Isi klausula baku sering kali merugikan pihak yang menerima klausula baku tersebut, yaitu pihak konsumen karena dibuat secara sepihak. Bila konsumen menolak klausula baku tersebut ia tidak akan mendapatkan barang ataupun jasa yang dibutuhkan, karena klausula baku serupa akan ditemuinya di tempat lain. Hal tersebut akan menyebabkan konsumen lebih sering setuju terhadap isi klausula baku walaupun memojokannya. Bagi para pengusaha mungkin ini merupakan cara mencapai tujuan ekonomi yang efisien, praktis, dan cepat tidak bertele-tele. Tetapi bagi konsumen justru merupakan pilihan yang tidak menguntungkan karena hanya dihadapkan pada satu pilihan, yaitu menerima walaupun dengan berat hati (Abdulkadir, 1992).

Istilah perjanjian baku merupakan terjemahan dari standard contract, baku berarti patokan dan acuan. Mariam Darus mendefinisikan baku adalah perjanjian yang isinya dibakukan dan dituangkan dalam bentuk formulir (Badrulzaman, 1978). Hondius merumuskan perjanjian baku sebagai konsep janji-janji tertulis, yang disusun tanpa membicarakan isi dan lazimnya dituangkan dalam perjanjian yang sifatnya tertentu, (Sudaryatmo, 1999) mengungkapkan karakteristik klausula baku sebagai berikut:

a. Perjanjian dibuat secara sepihak oleh mereka yang posisinya relatif lebih kuat dari kosnumen.

b. Konsumen sama sekali tidak dilibatkan dalam menentukan isi perjanjian.

c. Dibuat dalam bentuk tertulis dan massal. 
d. Konsumen terpaksa menerima isi perjanjian karena didorong oleh faktor kebutuhan.

$$
\text { Undang-Undang Perlindungan }
$$

Konsumen mendefinisikan, klausula baku adalah setiap aturan atau ketentuan dan syarat-syarat yang telah dipersiapkan dan ditetapkan terlebih dahulu secara seiphak oleh pelaku usaha yang dituangkan dalam suatu dokumen dan/atau perjanjian yang mengikat dan wajib dipenuhi oleh konsumen (Pasal 1 angka 10 UndangUndang Nomor 8 Tahun 1999 tentang Perlindungan Konsumen). (UndangUndang Nomor 8 Tahun 1999 Tentang Perlindungan Konsumen)

Perjanjian baku dengan klausula eksonerasinya pada prinsipnya hanya menguntungkan pelaku usaha dan merugikan konsumen, karena klausulanya tidak seimbang dan tidak mencerminkan keadilan. Dominasi pengusaha lebih besar dibandingkan dengan dominasi konsumen, dan konsumen hanya menerima perjanjian dengan klausula baku tersebut begitu saja karena dorongan kepentingan dan kebutuhan. beban yang seharusnya dipikul oleh pelaku usaha, menjadi beban konsumen karena adanya klausula eksonerasi tersebut.

Perjanjian eksonerasi yang membeaskan tanggung jawab seseorang pada akibatakibat hukum yang terjadi karena kurangnya pelaksanaan kewajibankewajiban yang diharuskan oleh perundang-undangan, antara lain tentang masalah ganti kerugian dalam hal perbuatan iangkar janji. Ganti rugi tidak dijalankan apabila dalam persyaratan eksonerasi tercantum hal itu (Zulham, 2013).

Akibat kedudukan para pihak yang tidak seimbang, maka pihak lemah biasanya tidak berada dalam keadaan yang betul-betul bebas untuk menuntukan apa yang diinginkannya dalam perjanjian. Dengan hal demikian, pihak yang memmiliki posisi yang lebih kuat biasanya menggunakan kesempatan tersebut untuk menentukan klausula-klausula tertentu dalam perjanjian baku. Sehingga perjanjian yang seharusnya dibuat oleh para pihak yang terlibat dalam perjanjian, tidak ditemukan lagi dalam bentuk perjanjian baku, karena format dan isi perjanjian telah dirancang oleh pihak yang kedudukannya lebih kuat (Zulham, 2013). Oleh karena yang merancang format dan isi perjanjian adalah pihak yang memiliki kedudukan lebih kuat, tentu saja dapat dipastikan bahwa perjanjian tersebut memuat klausula-klausula yang menguntungkannya. Serta bukan tidak mungkin juga meringankan atau menghapuskan beban dan kewajiban 
tertenty yang seharusnya menjadi tanggung jawabnya, (Zulham, 2013).

\section{Pengaturan}

\section{Pencantuman}

\section{Klausula Baku dalam UUPK}

Undang-Undang Perlindungan

Konsumen Pasal 18 ayat (1) melarang pelaku usaha untuk mencantumkan klausula baku pada setiap perjanjian dan dokumen apabila:

a. Menyatakan pengalihan tanggung jawab pelaku usaha.

b. Menyatakab bahwa pelaku usaha berhak menolak menyerahkan kembali barang yang dibeli konsumen.

c. Manyatakan bahwa pelaku usaha berhak menolak penyerahan kembali yang yang dibayarkan atas barang dan/atau jasa yang dibeli oleh konsumen.

d. Menyatakan pemberian kuasa dari konsumen kepada pelaku usaha baik secara langsung maupun tidak langsung untuk melakukan segala tindakan sepihak yang berkaitan dengan barang yang dibelikan oleh konsumen secara angsuran.

e. Mengatur perihal pembuktian atas hilangnya kegunaan barang atau pemanfaatan jasa yang dibeli oleh konsumen.

f. Memberi hak kepada pelaku usaha untuk mengurangi manfaat jasa atau mengurangi harta kekayaan konsumen yang menjadi objek jual beli jasa.

g. Menyatakan tunduknya konsumen kepada peraturan yang berupa aturan baru, tambahan, lanjutan da/atau pengubahan lanjutan yang dibuat sepihak oleh pelaku usaha dalam masa konsumen memanfaatkan jasa yang dibelinya.

h. Menyatakab bahwa konsumen memberi kuasa kepada pelaku usaha untuk pembebanan hak tanggungan, hak gadai, atau hak jaminan terhadap barang yang dibeli oleh konsumen secara angsuran.

Lebih lanjut lagi, Undang-Undang Perlindungan Konsumen pada Pasal 18 ayat (2) juga melarang pelaku usaha mencamtumkan klausula baku yang letak atau bentuknya sulit terlihat atau tidak dapat dibaca secara jelas, atau yang pengungkapannya sulit dimengerti. Dan setiap klausula baku yang telah ditetapkan oleh pelaku usaha pada dokumen atau perjanjian yang memenuhi ketentuan 
sebagaimana dimaksud pada ayat (1) dan ayat (2) dinyatakan batal demi hukum, dengan amar bahwa pelaku usaha wajib menyesuaikan klausula baku yang bertentangan dengan Undang-Undang Perlindungan Konsumen.

Tentu saja Undang-Undang Perlindungan Konsumen menginginkan terciptanya keseimbangan antara konsumen dengan pelaku usaha. pengaturan pencantuman klausula baku bukanlah merupakan keberpihakan terhadap kepentingan konsumen dan merugikan kepentingan pelaku usaha. Namun sesuai asas keseimbangan dalam hukum perlindungan konsumen, menginginkan kepentingan semua pihak harus dilindungi, termasuk kepentingan pemerintah dalam pembangunan nasional, harus mendapat porsi yang seimbang.

Penerapan klausula baku yang dilakukan oleh pihak dengan posisi lebih kuat akan merugikan pihak lain dengan posisi yang lebih lemah, biasanya model perjanjian seperti ini dikenal dengan penyalahgunaan keadaan (Badrulzaman, Aneka Hukum Bisnis, 1994), Memposisikan pelaku usaha dalam posisi yang lebih kuat daripada posisi konsumen, tidaklah selamanya benar. Karena dalam kasus tertentu posisi konsumen justru lebih kuat daripada posisi pelaku usaha, dan justru konsumenlah yang merancang klausula baku tersebut.
Dengan demikian pendapat di atas tidak selamanya (Miru, 2010)..

Perjanjian dengan klausula baku terjadi dengan beberapa cara hingga saat ini pemberlakuaan perjanjian baku tersebut antara lain dengan cara-cara ( (Nasution, 2002) :

1. Pencantuman butir-butir perjanjian yang konsepnya telah dipersiapkan terlebih dahulu oleh salah satu pihak, biasanya oleh kalangan pengusaha, produsen, distributor, atau pedagang produk tersebut. Perhatikan kontrak jual beli atau sewa beli kendaraan bermotor, perumahan, alat-alat elektronik, dan lain sebagainya.

2. Pencantuman klausula baku dalam lembaran kertas yang berupa tabel, bon, kuitansi, tanda terima, atau lembaran dalam bentuk serah terima barang. Seperti lembaran bon, kuitansi, atau tanda terkma barang dari toko, kedai, dan supermarket.

3. Pencantuman klausula baku dalam bentuk pengumuman tentang berlakunya syaratsyarat baku di tempat tertentu, seperti di area parkir, hotel, dan 
penginapan dengan meletakan atau menempelkan pengumuman klausula baku.

Memang klausula baku yang merupakan suatu bentuk perjanjian yang secara teoritis masih mengundang perdebatan, khususnya dalam kaitannya dengan asas kebebasan berkontrak (freedom of contract) dan syarat-syarat perjanjian. Dalam perjanjian baku, kebebasan dan pemberian kesepakatan untuk melakukan kontrak tidak dilakukan sebebas dengan perjanjian secara langsung, dengan melibatkan para pihak untuk menegosiasikan klausula perjanjian. Maka terdapat berbagai pendapat mengenai kedudukan klausula baku dalam hukum perjanjian.

Sluijter mengatakan bahwa klausula baku bukan merupakan perjanjian, sebab kedudukan pengusaha dalam perjanjian itu adalah seperti pembentuk undang-undang swasta (legio particuliere wetgever). Syarat-syarat yang ditentukan pengusaha dalam klausula itu adalah undang-undang, bukan perjanjian (Miru \& Yodo, 2011). Pitlo menggolongkan klausula baku sebagai perjanjian paksa (dwang contract). Walaupun secara teoritis yuridis, klausula baku tidak memenuhi ketentuan undangundang dan ditolak keberadaannya sebagai perjanjian oleh beberapa ahli hukum, namun kenyataanya kebutuhan masyarakat terhadap klausula baku berjalan ke arah yang berlawanan dengan keinginan hukum (Miru \& Yodo, 2011)

Stein mencoba memecahkan masalah ini dengan mengemukakan pendapat bahwa klausula baku dapat diterima sebagai perjanjian, berdasarkan fiksi adanya kemauan dan kepercayaan (fictie van wil en vertouwen) yang membangkitkan kepercayaan bahwa para pihak mengikaitkan diri pada perjanjian itu. Jika konsumen menerima dokumen klausula baku tersebut, berarti ia secara sukarela setuju pada isi perjanjian tersebut. Asser Rutten mengatakan bahwa setiap orang yang menandatangani perjanjian, bertanggung jawab pada isi dan apa yang ditandatanganinya. Jika ada orang yang membubuhkan tanda tangan pada formulir perjanjian baku, tanda tangan itu akan membangkitkan kepercayaan bahwa yang bertanda tangan mengetahui dan menghendaki isi formulir yang ditandatangani. Tidak mungkin seseorang menandatangani apa yang tidak diketahui isinya. Hondius dalam disertasinya mempertahankan bahwa perjanjian baku mempunyai kekuatan mengikat berdasarkan kebiasaan yang berlaku di masyarakat dan perdagangan. 
(Miru A. , 2010) berpendapat bahwa perjanjian baku merupakan perjanjian yang mengikat para pihak yang menandatanganinya, walaupun harus diakui bahwa klausula yang terdapat dalam perjanjian baku banyak mengalihkan beban tanggung jawab dari pihak perancang klausula baku kepada pihak lawannya. Namun setiap kerugian yang timbul dikemudian hari akan tetap ditanggung oleh para pihak yang harus bertanggung jawab berdasarkan klausula perjanjian tersebut, kecuali jika klausula tersebut merupakan klausula yang dilarang berdasarkan Pasal 18 Undang-Undang Perlindunngan Konsumen.

Kendatipun demikian, harus pula diakui bahwa perjanjian baku sangat dibutuhkan dalam dunia perdagangan yang semakin pesat dewasa ini. Dengan penggunaan klausula baku tersebut, berarti para pihak dapat mempersingkat waktu bernegosiasi. Di samping itu, perjanjian baku yang tetap mengikat para pihak dan pada umumnya beban tanggung jawab para pihak adalah berat sebelah. Maka langkah yang harus dilakukan bukan melarang atau membatasi penggunaan klausula baku, melainkan melarang atau membatasi penggunaan klausa-klausa tertentu dalam perjanjian baku tersebut (Philips, 1993).
Upaya perlindungan konsumen di atas tentu sangatlah terbatas, dan tidak mungkin memberikan perlindungan konsumen kepada konsumen secara keseluruhan. Akan tetapi upaya tersebut dapat dijadikan untuk membatasi kerugian akibat penggunaan klausula baku. Pembatasan atau larangan pencantuman klausula baku tertentu dalam perjanjian tersebut, dimaksudkan untuk mencegah terjadinya penyalahgunaan keadaan oleh pihak yang memiliki kedudukan lebih kuat, yang pada akhirnya akan merugikan konsumen.

\section{B. Pengaturan Klausula Baku dalam Perspektif Hukum Perikatan Syariah}

Setiap orang mempunyai kebebasan ntuk melakukan perjanjian dengan siapapun. Perjanjian antara satu piuhak dengan pihak lain tersebut bersifat privat, artinya hanya mengikat kedua belah pihak. Oleh karena itu, pihak lain tidak mempunyai hak untuk ikut campur dalam perjanjian tersebut. Negara hanya bisa melakukan intervensi dalam hubungan privat/perdata apabila salah satu pihak yang melakukan hubungan perdata berada dalam posisi yang lemah, negara mempunyai tugas untuk melindungi pihak yang lemah tersebut agar mempunyai 
posisi yang kuat, tidak berat sebelah (Misbuk van Omstandingheden).

Misalnya, bahwa perjanjian itu harus memenuhi syarat-syarat sahnya suatu perjanjian, bahwa materi perjanjian (Pasal 1320 KUH Perdata), bahwa meteri perjanjian tidak boleh bertentangan dengan peraturan perundang-undangan yang berlaku, ketertiban umum dan kesusilaan (Pasal 1338 ayat 3) dan bahwa perjanjian tidak boleh timbul akibat dari adanya paksaan, kekhilafan (Pasal 1322 KUH Perdata) ataupun penipuan, dan lain-lain.

Sedangkan apabila seseorang telah melakukan perjanjian, apa pun bentuk perjanjian tersebut, baik jual beli, sewa menyewa, dan lain sebagainya, asalkan tidak bertentangan dengan hal-hal tersebut di atas maka perjanjian tersebut tetap sah dan tidak ada otoritas manapun yang berhak membatalkan kecuali atas kesepakatan kedua belah pihak. Hal yang menyangkut perlilaku atau keadaan demikian adalah apa yang disebut dengan "asas kebebasan berkontrak".

Asas kebebasan berkontrak ini dalam hukum positif diatur dalam Pasal 1338 ayat (1) KUHPerdata yang berbunyi, "semua perjanjian yang dibuat secara sah berlaku sebagai undang-undang bagi mereka yang membuatnya". Sementara batasan-batasan yang diberikan oleh pembentuk undang-undang tercantum dalam Pasal 1338 ayat (2), Pasal 1320, Pasal 1321 dan Pasal 1337 KUHPerdata.

Hukum perikatan Syarah/Islam pada prinsipnya mengatur asas kebebasan berkontrak yang dituangkan dalam prinsip "Antarâdhin minkum" sebagaimana diatur dalam Q.S al-Nisa (4) ayat 29, dan hadis Nabi Muhammad Saw yaitu sesuatu perkara atau perjanjian akan sah dan mengkat kedua belah pihak apabila ada kesepakatan (antarâdhin) yang terwujud dalam 2 dua pilar, yaitu ijab (penawaran) dan kabul (penerimaan), namun demikian tentunya terdapat perbedaan dalam konsep syariah dan berttik tolak dari firman Allah Swt dalam al-Quran dan juga pernyataan dan perilaku Nabi Muhammad Saw dalam hadis (Gemala Dewi, 2007: 204-208).

Dengan demikian tentu saja ada perbedaan yang esensial dalam pembatasan-pembatasan yang diberikan kedua konsep tersebut. Apabila dalam hukum positif pembatasan yang ditentukan oleh negara hanya berkaitan dengan hakhak manusia sebagaimana yang dikemukakan di atas. Dalam kontrak syariah paling tidak ada hal-hal yang perlu diperhatikan dalam pembuatan suatu kontrak antara lain adalah sebagai berikut: (1) hal yang diperjanjikan dan objek transaksi haruslah halal menurut syariah; (2) tidak terdapat ketidakjelasan (gharar) dalam rumusan akad maupun prestasi yang 
diperjanjikan; (3) para pihaknya tidak menzalimi dan tidak dizalim; (d) transaksi harus adil; (5) transaksi tidak mengandung unsur spekulatif/perjudian (maysir); (6) terdapat prinsip kehati-hatian; (7) tidak membuat barang-barang yang tidak bermanfaat dalam Islam ataupun barang najis; dan (8) tidak mengandung riba (Nur Melinda Lestari, 2015: 135).

Dalam praktik akad syariah, pembatasan-pembatasan tersbeut bisa dijadikan penjelasan bagi konsep "klausula yang halal" sebagai syarat sah pejanjian menurut Pasal 1320 KUHPerdata yang kni dipakai dalam perjanjian kontrak baku dalam dunia perjanjian dan perasuransian. Dewasa ini, Bank Indonesia sedang megupayakan pembuatan standarisasi akad-akakd syariah untuk diterapkan dalam kontrak-kontrak yang akan diterapkan pada bank-bank syariah di Indonesia.

Di samping asas-asas di atas, terdapat prinsip-prinsip yang melandasi konsep hukum perikatan syariah yang merupakan prinsip-prinsip dalam melakukan transaksi muamalah. Adapun prinsip-prinsip yang menjadi pedoman dalam pelaksanaan transaksi muamalah adalah sebagai berikut: (1) prinsip antarâdin (prinsip konsensualisme/suka sama suka); (2) prinsip al-i'timad alâ alnafs (kewirausahaan); (3) prinsip ta'âwun (saling tolong menolong); prinsip masuluiyah (tanggung jawab); (4) prinsip al-taysîr(kemudahan), karena segala kegiatan dalam bermmuamalah dibolehkan sepanjang tidak ada larangan syara (Q.S 25: 67); (5) prinsip al-idâriyah (administasi keuangan yang benar dan transparan); (6) prinsip al-takâful alijtimâ'iy (tanggung jawab sosial); dan prinsip al-ihtiyâth (prudencial/kehatihatian).

Kontrak atau perjanjian pada dasarnya dibuat berlandaskan pada asas kebebasan berkontrak di antara dua pihak yang memiliki kedudukan seimbang dan kedua pihak berusaha mencapai kata sepakat melalui proses negosiasi. Dalam perkembangannya, banyak perjanjian dalam transaksi bisnis bukan terjadi melalui negosiasi yang seimbang di antara para pihak. Salah satu pihak telah menyiapkan syarat-syarat bakupada formulir perjanjian yang sudah ada kemudian disodorkan kepada pihak lain untuk disetujui dengan hampir tidak memberikan kebebasan sama sekali kepada pihak lainnya untuk melakukan negosiasi atas suatu syarat-syarat yang disodorkan. Perjanjian yang demikian disebut sebagai perjanjian baku atau perjanjian standar atau juga perjanjian adhesi (Syahdeni, 1993). Kata baku atau standar artinya tolok ukur yang dipakai 
sebagai patokan atau pedoman bagi setiap konsumen yang menandakan hubungan hukum dengan pengusaha, yang dibakukan dalam perjanjian baku meliputi model, rumusan dan ukuran (Abdulkadir, 1992)

Ada 5 (lima) prinsip-prinsip syariah yang melandasi kebasahan klausula baku adalah sebagai berikut: Pertama, Hurriyah at-Ta'uqud atau kebebasan berkontrak. Prinsip hurriyah at-Ta'uqud merupakan wujud dari kebebasan berkontrak. Masing-masing pihak yang akan mencapai tujuan akad mempunyai kebebasan untuk mengadakan penyusunan perjanjian atau freedom of making contract. Asas kebebasan berkontrak merupakan suatu asas yang universal sebagaimana dikutip oleh Agus Yudha Hernoko dari pendapat Sutan Remy Sjahdeni bahwa sebagai asas yang bersifat universal yang bersumber dari paham hukum, asas kebebasan berkontrak atau freedom of contract itu muncul bersamaan dengan lahirnya paham ekonomi klasik yang mengagungkan laissez faire atau persaingan bebas. Menurut Agus Yudha Hernoko bahwa asas kebebasan berkontrak adalah menempatkan para pihak yang berkontrak dalam posisi yang setara secara proposional, asas ini tidak menempatkan para pihak untuk saling berhadapan, menjatuhkan dan mematikan sebagai lawan kontrak justru sebaliknya asas ini menempatkan para pihak sebagai partner mitra kontrak pertukaran kepentingan mereka (Agus Yudha Hernoko, 2007:112).

Kedua, Ash-Shiddiq atau kejujuran. Kejujuran merupakan hal yang prinsip bagi manusia dalam segala aspek bidang kehidupan, termasuk di dalam penyusunan kontrak muamalah. Jika kejujuran tidak diamalkan dalam penyusunan kontrak, maka akan merusak keridhaannya (uyub al-ridha). Di samping itu, ketidakjujuran di dalam penyusunan perjanjian akan berakibat perselisihan di antara para pihak. Allah berfirman: "Hai orang-orang yang beriman, bertakwalah kamu kepada Allah, dan berkatalah perkataan yang benar" (QS. Al-Ahzab (33):70). Dalam haditsnya Rasulullah SAW bersabda: "Jika kamu menjual barang dagangan, maka katakanlah tidak ada penipuan" (HR. Bukhari). Berdasarkan kutipan ayat Al Quran dan juga Al Hadits tersebut, diketahui bahwa di dalam hukum kontrak syariah sangat menekankan adanya prinsip kejujuran yang hakiki, karena hanya dengan prinsip kejujuran itulah keridhaan dari para pihak yang membuat perjanjian dapat terwujud (Abdul Ghofur Anshori, 2006:46).

Ketiga, Itikad Baik. Untuk dpapat mengadakan kontrak haruslah dilaksanakan berdasarkan itikad baik. Di dalam pandangan Islam, niat merupakan 
prinsip mendasar terkait dengan unsur kepercayaan sebelum dapat melakukan suatu amal perbuatan. Dalil syariah yang menjadi dasar hukum berlakunya asas itikad baik adalah hadits Nabi yang menyatakan: "Sesungguhnya amal perbuatan tergantung pada niat, dan sesungguhnya tiap-tiap orang tergantung dari apa yang diniatkannya" (HR. Bukhari). Demikian juga dalam hadits Nabi Saw: "Orang yang terbaik di antara kamu adalah orang yang paling baik dalam pembayaran akan hutangnya". (HR Bukhari) (Abdul Ghofur Anshori, 2006:46).

Keempat, Al Amanah atau kepercayaan. Amanah merupakan bentuk kepercayaan yang timbul karena adanya itikad baik dari masing-masing pihak untuk mengadakan akad. Dalam hukum perjanjian syariah, terdapat bentuk akad yang bersifat amanah. Maksud amanah disini dapat diartikan sebagai kepercayaan kepada pihak lain untuk kemudian menjalin kerja sama. Dasar hukumnya ialah dari firman Allah yang menyatakan bahwa: "Sesungguhnya Allah menyuruh kamu menyampaikan amanat kepada yang berhak menerima" (QS. An-Nisa (4):58). "Maka hendaklah yang dipercayai itu menunaikan amanatnya" (QS. Al Baqarah (2):283) "Wahai orang-orang yang beriman! Janganlah kamu mengkhianati
Allah dan Rasul dan (juga) janganlah kamu mengkhianati amanat yang dipercayakan kepadamu, sedang kamu mengetahui" (QS. Al Anfal (8):27). Surat Al-Anfal ini tercantum pada akad pembiayaan di perbankan syariah sebagai dasar bahwasanya hubungan antara bank syariah dan nasabah didasarkan pada amanah sehingga harus dijaga amanah tersebut.

Kelima, Al Adalah atau keadilan. Pelaksanaan dari prinsip ini dalam suatu perjanjian atau akad menuntut para pihak untuk melakukan yang benar di dalam pengungkapan suatu kehendak dan keadaan, memenuhi semua kewajibannya. Perjanjian harus senantiasa mendatangkan keuntungan yang adil dan seimbang, serta tidak boleh mendatangkan kerugian bagi salah satu pihak. Untuk itu Allah berfirman: "Hai orang-orang yang yang beriman, hendaklah kamu jadi orangorang yang selalu menegakkan kebenaran karena Allah, menjadi saksi dengan adil. Dan janganlah sekali-kali kebencianmu terhadap suatu kaum, membuat kamu cenderung untuk akhirnya berlaku tidak adil. Berlaku adillah karena adil itu lebih dekat kepada takwa. Dan bertakwalah kepada Allah, sesungguhnya Allah Maha Mengetahui apa kamu kerjakan" (QS. Al Maidah (5):8) (Abdul Ghofur Anshori, 2006:27). 


\section{SIMPULAN}

Dari uraian di atas dapat disimpulakan bahwa klausula baku adalah setiap aturan atau ketentuan dan syaratsyarat yang telah dipersiapkan dan ditetapkan terlebih dahulu secara sepihak oleh pelaku usaha yang dituangkan dalam suatu dokumen dan/atau perjanjian yang mengikat dan wajib dipenuhi oleh konsumen. Ketentuan pencantuman klausula baku diatur dalam Pasal 18 UUPK. UUPK menginginkan terciptanya kesimbangan antara konsumen dan pelaku usaha. Pengaturan pencantuman klausula baku bukanlah merupakan keberpihakan terhadap kepentingan konsumen dan merugikan kepentingan pelaku usaha. Namun sesuai asas keseimbangan dalam hukum perlindungan konsumen menginginkan kepentingan semua pihak harus dilindungi, termasuk kepentingan pemerintah dalam pembangunan nasional, harus mendapat porsi yang seimbang.

Pada dasarnya, dalam hukum perjanjian syariah ketentuan mengenai klausula baku bersumber dari asas alhurriyah (kebebasan berkontrak) yang dituangkan dalam prinsip "Antarâdhin minkum" sebagaimana diatur dalam Q.S al-Nisa (4) ayat 29.

Landasan keabsahan klausula baku dalam hukum perjanjian syariah terdapat dalam prinsip-prinsip perjanjian, seperti prinsip al-hurriyah, prinsip al-'Adl, prinsip amah, prinsip al-shidiq dan prinsip itikad baik.

\section{Daftar Pustaka}

Abdulkadir, M. (1992). Perjanjian Baku dalam Praktik Perusahaan Perdagaan. Bandung: PT. Citra Aditya Bakti.

Badrulzaman, M. D. (1994). Aneka Hukum Bisnis. Bandung: Alumni.

Badrulzaman, M. D. (1978). Perjanjian

Kredit Bank. Bandung: Alumni.

Dirdjosisworo, Soedjono. (2003) Kontrak Bisnis, Menurut Sistem Civil Law, Common Law dan Praktik Dagang Internasional. Bandung: Mandar Maju.

Gemala Dewi. (2007). Aspek-Aspek Hukum dalam Perbankan dan Perasuansian Syariah di Indonesia. Jakarta: Kencana.

Gunawa Widjaja dan Ahmad Yani. (2003). Hukum tentang Perlindungan Konsumen. Gramedia: Jakarta.

Hasanuddin Rahman. (2003). Seri Keterampilan Merancang Kontrak Bisnis, Contract Drafting. Bandung: Citra Aditya Bakti. 2003 
Karla, C. Shippey J.D. (2001). Menyusun Kontrak Bisnis Internasional. Jakarta: PPM.

Miru, A. (2010). Prinsip-prinsip Perlindungan Hukum Bagi Konsumen di Indonesia. Surabaya: Universitas Airlangga.

Miru, A., \& Yodo, S. (2011). Hukum Perlindungan Kosumen. Jakarta: PT. Raja Grafindo Persada.

Munir Fuady. (2001). Hukum Kontrak, dari Sudut Pandang Hukum Bisnis, Citra Adiyta Bakti, Bandung, 2001.

Nasution, A. (2002). Hukum Perlindungan

Konsumen. Jakarta: Diadit Media.

Nur Melinda Lestari. (2015). Sistem Pembiayaan Bank Syariah: Berdasarkan UU No. 21 Tahun 2008. Jakarta: Grafndo Books Media.

Peter Mahmud Marzuki. (2002). Kontrak Bisnis Internasional. Surabaya: Magister Hukum Universita Airlangga

Philips, J. J. (1993). Product Liability. St. Paul: Wet Publishing Company.

Pieries, J., \& Widiarty, W. S. (2007). Negara Hukum Dan Perlindungan Konsumen Terhadap Produk
Perdagangan Kadaluarsa. Jakarta: Pelangi Pendikia.

Saputra, P. A. (2017). Kedudukan Sertifikasi Halal Dalam Sistem Hukum Nasional Sebagai Upaya Perlindungan Konsumen Dalam Hukum Islam. Amwaluna : Jurnal Ekonomi dan Keuangan Syariah, Vol 1, No 1.

Sidabalok, J. (2010). Hukum Perlindungan Konsumen di Indonesia. Bandung: PT. Citra Aditya Bakti.

Sudaryatmo. (1999). Hukum dan Advokasi Konsumen. Bandung: PT. Citra Aditya Bakti.

Syahdeni, S. R. (1993). Kebebasan Berkontrak Dan Perlindungan Yang Seimbang Bagi Para pihak dalam Perjanjian Kredit Bank. Jakarta: IBI.

Undang-Undang Nomor 8 Tahun 1999 Tentang Perlindungan Konsumen.

Widijantoro, J. Product Liability dan Perlindungan Kondumen di Indonesia, Jurnal Justitia Et Pax Juli-Agustus 1998. 
Amwaluna: Jurnal Ekonomi dan Keuangan Syariah Vol. 1 No.2 (Juli, 2017), Hal 200-216

Zulham. (2013). Hukum Perlindungan

Prenada Media Group.

Konsumen. Jakarta: Kencana 